\title{
Peningkatan Prestasi Belajar IPA Siswa Pada Model Pembelajaran Learning Cycle Dengan Materi Energi dan Perubahannya
}

\author{
Darmawan Harefa \\ STKIP Nias Selatan \\ email : harefadarmawan@gmail.com
}

\begin{abstract}
The purpose of this research to find out the improvement students' science learning achievement in the Learning Cycle learning model on energy material and its changes. This type of research is quantitative research with experimental methods. Based on the research results obtained: (1) the average value on the initial test in the experimental class was 70 while the average value of the initial test in the control class was 69.86. (2) The average value of the final test in the experimental class was 84.22, while the average value of the final test in the control class was 73.39. (3) Based on the calculation of the hypothesis test obtained thitung $=3,746>$ ttable $=1,667$. This shows the value of $t>t$ table. Because the value of $t>t$ table then Ha is accepted and Ho rejected at significant level of 5\%. So it can be concluded that the increase in science learning achievement of students in the Learning Cycle learning model has positive effect on student achievement in energy material and its changes in Class VI of Lagundri Country. Researcher's suggestion: It is expected that every science subject teacher applies the Learning Cycle learning model to improve student learning achievement.
\end{abstract}

Keywords: Achievement, natural science learning, Lerning Cycle Learning, Energy and Changes

\begin{abstract}
Abstrak
Tujuan penelitian yaitu untuk mengetahui peningkatan prestasi belajar IPA siswa pada model pembelajaran Learning Cycle pada materi energi dan perubahannya. Jenis penelitian ini adalah penelitian kuantitatatif dengan metode eksperimen. Berdasarkan hasil penelitian diperoleh : (1) nilai rata-rata pada tes awal di kelas eksperimen adalah 70 sedangkan nilai rata-rata tes awal di kelas kontrol adalah 69,86. (2) Nilai rata-rata tes akhir di kelas eksperimen adalah 84,22 , sedangkan nilai rata-rata tes akhir di kelas kontrol adalah 73,39. (3) Berdasarkan perhitungan uji hipotesis diperoleh $t_{\text {hitung }}=3,746>t_{\text {tabel }}=1.667$. Hal ini menunjukkan nilai $t_{\text {hitung }}>t_{\text {tabel }}$. Karena nilai $t_{\text {hitung }}>t_{\text {tabel }}$ maka Ha diterima dan Ho ditolak pada taraf signifikan 5\%. Maka dapat disimpulkan bahwa peningkatan prestasi belajar IPA siswa pada model pembelajaran Learning Cycle berpengaruh positif terhadap prestasi belajar siswa pada materi energi dan perubahannya di kelas VI Negeri Lagundri. Saran peneliti: diharapkan kepada setiap guru mata pelajaran IPA supaya menerapkan model pembelajaran Learning Cycle demi peningkatkan prestasi belajar siswa.
\end{abstract}

Kata Kunci: Prestasi, belajar IPA, Pembelajaran Lerning Cycle, Energi dan Perubahannya 


\section{Harefa}

\section{PENDAHULUAN}

Dunia pendidikan harus mampu meyakinkan bahwa sumber daya manusia yang dihasilkan berkompetensi dalam bidang ilmu yang dimiliki dan mampu bersaing dalam era globalisasi. Seperti yang kita ketahui saat ini, persaingan pendidikan sangat ketat. pendidikan merupakan hal penting dalam membangun peradaban bangsa (Harefa, 2017).

Belajar salah suatu proses usaha yang dilakukan seseorang untuk memperoleh suatu perubahan belajar yang baru secara keseluruhan. Menurut (Slameto, 2010) bahwa "Belajar ialah suatu proses usaha yang dilakukan seseorang untuk memperoleh suatu perubahan tingkah laku yang baru secara keseluruhan, sebagai hasil pengalamannya sendiri dalam interaksi dengan lingkungannya".

Belajar bukanlah sekedar mengumpulkan pengetahuan (Aunurrahman, 2016). Namun, belajar adalah proses mental yang terjadi dalam diri seseorang, sehingga menyebabkan munculnya perubahan belajar. Aktivitas mental itu terjadi karena adanya interaksi dengan lingkungan. Berhubungan dengan hal itu. (Rusman, 2012) menyatakan bahwa "belajar pada hakikatnya adalah proses interaksi terhadap semua situasi yang ada di sekitar individu". Di samping definisidefinisi di atas, maka dapat diterangkan bahwa "belajar itu senantiasa merupakan perubahan tingkah laku atau penampilan, dengan serangkaian kegiatan misalnya dengan membaca, mengamati, mendengarkan, meniru dan lain sebagainya (Sardiman, 2011).

Menurut (Hamdani, 2010) bahwa "prestasi adalah hasil dari suatu kegiatan yang telah dikerjakan diciptakan, baik secara individual maupun kelompok". Selanjutnya mengatakan bahwa "prestasi belajar merupakan bukti keberhasilan yang telah dicapai oleh seseorang". (Khairani, 2013) bahwa "orang yang mempunyai motivasi berprestasi tinggi akan sangat senang ia berhasil memenangkan suatu persaingan".

Prestasi belajar salah satu penilaian hasil usaha kegiatan belajar yang dinyatakan dalam bentuk simbol angka, huruf maupun kalimat yang dapat mencerminkan hasil yang sudah dicapai oleh setiap anak didik dalam periode tertentu. Menurut (Istarani, 2012) bahwa "Prestasi belajar adalah hasil dari suatu kegiatan yang telah dikerjakan, diciptakan, baik secara individual maupun secara kelompok". Prestasi tidak akan pernah dihasilkan selama seseorang tidak melakukan kegiatan (Harefa, 2017). Menurut (Syah, 2015) bahwa "evaluasi artinya penilaian terhadap tingkat keberhasilan siswa mencapai tujuan yang telah ditetapkan dalam sebuah program".

Berdasarkan pendapat para ahli di atas, maka penulis dapat menyimpulkan bahwa prestasi belajar adalah pencapaian atau kecakapan yang dinampakkan dalam keahlian atau kumpulan pengetahuan. Pengetahuan, pengalaman dan 
keterampilan yang diperoleh akan membentuk kepribadian siswa, memperluas kepribadian siswa, memperluas wawasan kehidupan serta meningkatkan kemampuan siswa.

Model pembelajaran biasanya dijadikan sebagai parameter untuk melihat sejauh mana siswa dapat menerima dan menerapkan materi yang disampaikan guru dengan mudah dan menyenangkan dengan model yang diterapkan. (Trianto, 2014) model pembelajaran adalah suatu perencanaan atau suatu pola yang digunakan sebagai pedoman dalam merencanakan pembelajaran di kelas atau pembelajaran dalam tutorial. "Proses pembelajaran mempunyai tujuan agar siswa dapat mencapai kompetensi seperti yang diharapkan (Benny, 2009). Penerapan model pembelajaran yang bervariasi akan mengatasi kejenuhan siswa sehingga dapat dikatakan bahwa model pembelajaran sangat berpengaruh terhadap tingkat prestasi siswa. Aktivitas belajar siswa merupakan salah satu faktor penting dalam kegiatan belajar mengajar. Hal ini mengingatkan bahwa kegiatan belajar mengajar diadakan dalam rangka memberikan pengalamanpengalaman belajar pada siswa. Jika siswa aktif dalam kegiatan tersebut kemungkinan besar akan dapat mengambil pengalaman-pengalaman belajar tersebut. Kegiatan belajar dipandang sebagai kegiatan komunikasi antara siswa dan guru. Menurut (Mulyasa, 2006) bahwa "guru adalah pendidik, yang menjadi tokoh, panutan, dan identifikasi bagi para pesrta didik, dan lingkungannya". Keberhasilan suatu proses pembelajaran sangat ditentukan oleh kualitas atau kemampuan guru dalam menerapkan model pembelajaran.

Pada saat pembelajaran sedang berlangsung, siswa cenderung bosan, malas belajar disebabkan tidak ada variasi model pembelajaran yang menarik (Harefa, 2018). Model pembelajaran yang bervariasi belum menerapkan model pembelajaran Learning Cycle sehingga keterlibatan guru dan siswa dalam kegiatan pembelajaran kurang optimal.

Model pembelajaran

Learning Cycle yaitu suatu model pembelajaran yang berbasis konstruktivisme artinya pengetahuan tidak dapat dipindahkan begitu saja dari pikiran guru ke pikiran siswa bahwa siswa harus aktif secara mental membangun struktur pengetahuannya berdasarkan kematangan kognitif yang dimilikinya. Learning cycle merupakan rangkaian tahap-tahap kegiatan yang diorganisasi

sedemikian rupa sehingga siswa dapat menguasai kompetensi-kompetensi yang harus dicapai dalam pembelajaran dengan jalan berperan aktif dalam proses pembelajaran. Jadi, model pembelajaran learning cycle adalah pembelajaran bersiklus yang membuat siswa aktif untuk memanfaatkan peluang untuk situasi yang baru.

Oleh sebab itu perlu dilakukan upaya peningkatan prestasi belajar siswa terlebih-lebih dalam 


\section{Harefa}

mata pelajaran IPA melalui model yang dapat melibatkan siswa secara langsung dan nyata dalam proses pembelajaran sehingga siswa tidak hanya pasif dan bertindak sebagai pendengar dan prestasi belajar siswa dapat dicapai dengan maksimal, serta ada interaksi antara guru dan siswa sehingga motivasi belajar akan timbul dengan sendirinya (Harefa, 2019). Untuk mencapai tujuan di atas, maka diperlukan usaha-usaha untuk meningkatkan mutu pendidikan yang baik salah satunya yaitu dengan menggunakan model pembelajaran yang melibatkan siswa secara aktif guna menunjang kelancaran proses belajar mengajar dan mengembangkan pola pikir siswa, salah satunya yaitu dengan menggunakan model pembelajaran Learning Cycle.

Model pembelajaran

Learning Cycle merupakan suatu metode pembelajaran yang mendorong dan menekankan siswa untuk menemukan dan menyelesaikan persoalan-persoalan yang kemudian didiskusikan untuk memperoleh kesimpulan sehingga siswa menjadi seorang individu yang mampu belajar mandiri. Menurut (Shoimin, 2014) bahwa "model pembelajaran Cycle Learning (pembelajaran bersiklus), yaitu suatu model pembelajaran yang berpusat pada siswa (student centered)". Model pembelajaran Learning Cycle hendaknya dapat dipelajari, dalam pengembangan aspek kognitif yang meliputi: struktur, isi, dan fungsi. Struktur intelektual adalah organisasi- organisasi mental tingkat tinggi yang dimiliki individu untuk memecahkan masalah baik di dalam keluarga, maupun dalam masyarakat.

\section{METODE PENELITIAN}

Jenis penelitian yang gunakan adalah penelitian quasi eksperimen dengan pendekatan kuantitatif. Penelitian eksperimen menurut (Sudjana, 2014) bahwa "metode yang mengungkapkan hubungan antara dua variabel atau lebih atau mencari pengaruh suatu variabel terhadap variabel lainnya". Dengan demikian eksperimental adalah penelitian yang dilakukan dengan mengadakan manipulasi terhadap objek penelitian serta adanya kontrol. Berdasarkan pendapat di atas, tujuan menggunakan rancangan eksperimen yakni meneliti sebab akibat suatu perlakuan perbedaan rata-rata hasil belajar siswa dengan menerapkan model pembelajaran Learning Cycle di kelas VI SD Negeri Lagundri.

Tabel. 1. Desain Penelitian

\begin{tabular}{cccc}
\hline Kelas & $\begin{array}{c}\text { Tes } \\
\text { Awal }\end{array}$ & Perlakuan & $\begin{array}{c}\text { Tes } \\
\text { Akhir }\end{array}$ \\
\hline $\begin{array}{c}\text { Kelas } \\
\text { Ekserimen }\end{array}$ & $\mathrm{T}_{1(\mathrm{e})}$ & $\mathrm{X}_{\mathrm{e}}$ & $\mathrm{T}_{2(\mathrm{e})}$ \\
\hline $\begin{array}{c}\text { Kelas } \\
\text { kontrol }\end{array}$ & $\mathrm{T}_{1(\mathrm{c})}$ & $\mathrm{X}_{\mathrm{c}}$ & $\mathrm{T}_{2(\mathrm{c})}$ \\
\hline
\end{tabular}

Keterangan:

$\mathrm{T}_{1(\mathrm{e})}=\mathrm{T}_{1(\mathrm{e})}=$ Pemberian tes awal $\mathrm{X}_{\mathrm{e}}=$ Perlakuan menerapkan model pembelajaran Learning Cycle $\mathrm{X}_{\mathrm{c}}=$ Perlakuan menerapkan model ceramah $\mathrm{T}_{2(\mathrm{e})}=\mathrm{T}_{2(\mathrm{e})}=$ Pemberian tes akhir 
Prosedur

pelaksanaan

pengajaran antara lain: (1) Tes awal (pretest) disebarkan kepada kedua kelas yakni kelas eksperimen dan kelas kontrol (2) Diberikan perlakuan untuk kedua kelas yakni untuk kelas eksperimen menggunakan model pembelajaran Learning Cycle dan untuk kelas kontrol menggunakan metode ceramah (3) Setelah disajikan materi kondisi fisik wilayah penduduk untuk kedua kelas diberikan tes akhir (posttest) (4) Prestasi belajar siswa pada tes awal maupun pada tes akhir dianalisa sesuai dengan rumus statistika.

Instrumen data yang digunakan dalam penelitian ini adalah teknik tes dalam bentuk tes uraian yang disusun berdasarkan kisi-kisi tes dengan memperhatikan aspek-aspek ranah kognitif. Tes awal diberikan kepada kedua sampel penelitian dengan bentuk tes uraian sebanyak 5 (lima) butir soal. Tes awal ini dilaksanakan sebelum diberikan perlakuan dengan melaksanakan model pembelajaran Learning Cycle pada kelas ekseprimen dan model pembelajaran konvensional pada kelas kontrol yang bertujuan untuk menguji normalitas dan homogenitas kedua kelas yang berperan sebagai sampel penelitian.

Tes akhir merupakan kegiatan terakhir yang dilakukan kepada kedua kelas, baik kelas eksperimen maupun kelas kontrol. Tes akhir ini berbentuk tes uraian sebanyak 5 (lima) butir soal, berdasarkan kisi-kisi tes yang telah disusun oleh peneliti dengan memperhatikan aspek-aspek kognitif dari materi yang telah ditetapkan.

\section{HASIL DAN PEMBAHASAN}

\section{Hasil Tes Awal pada Kelas Eksperimen}

Melalui pemberian tes awal kepada kelas eksperimen, maka dapat dibuat frekuensi hasil belajar siswa, sebagai berikut:

Tabel. 2. Frekuensi Perolehan Skor Tes Awal Kelas Eksperimen

\begin{tabular}{|c|c|c|}
\hline Nilai (x) & $\begin{array}{c}\text { Frekuensi } \\
\left(\mathbf{f}_{\mathbf{i}}\right)\end{array}$ & $\begin{array}{c}\text { Nilai total } \\
\left(\mathbf{x . f}_{\mathbf{i}}\right)\end{array}$ \\
\hline 50 & 5 & 250 \\
\hline 60 & 4 & 240 \\
\hline 65 & 4 & 260 \\
\hline 70 & 5 & 350 \\
\hline 75 & 3 & 225 \\
\hline 80 & 6 & 480 \\
\hline 85 & 3 & 255 \\
\hline 90 & 2 & 180 \\
\hline Jumlah & 32 & 2240 \\
\hline
\end{tabular}

Berdasarkan tabel .2. di atas dapat diketahui bahwa nilai tertinggi adalah 90 dan nilai terendah adalah 50, yaitu siswa yang memperoleh nilai 90 sebanyak 2 orang, siswa yang memperoleh nilai 85 sebanyak 3 orang, siswa yang memperoleh nilai 80 sebanyak 6 orang, siswa yang memperoleh nilai 75 sebanyak 3 orang, siswa yang memperoleh nilai 70 sebanyak 5 orang, siswa yang memperoleh nilai 65 sebanyak 4 orang, siswa yang memperoleh nilai 60 sebanyak 4 orang, dan siswa yang memperoleh nilai 50 sebanyak 5 orang.

Berdasarkan tes hasil belajar siswa di atas, perhitungan nilai yang 


\section{Harefa}

digunakan adalah bentuk essey tess, maka untuk menentukan rata-rata hitung penelitian menggunakan rumus:

$$
\overline{\mathrm{X}}=\frac{\Sigma_{x}}{\mathrm{~N}}=\frac{2240}{32}=70
$$

Berdasarkan data hasil tes awal kelas eksperimen, maka data tersebut dapat digunakan untuk menentukan simpangan baku dengan rumus sebagai berikut ini:

$$
\begin{aligned}
& S^{2}=\frac{\left.(N)\left(E x^{2}\right)-(E x)^{2}\right)}{N(N-1)} \\
& =\frac{32(161450)-(2240)^{2}}{32(32-1)}=150, S=12,25
\end{aligned}
$$

\section{Hasil Tes Awal Kelas Kontrol Belajar Kognitif Siswa}

Melalui pemberian tes awal kepada kelas kontrol maka dapat dibuat tabel. 3 frekuensi hasil belajar siswa, sebagai berikut:

Tabel. 3. Frekuensi Perolehan Skor Tes Awal Kelas Kontrol

\begin{tabular}{ccc}
\hline Nilai $(\mathbf{x})$ & $\begin{array}{c}\text { Frekuensi } \\
\left(\mathbf{f}_{\mathbf{i}}\right)\end{array}$ & $\begin{array}{c}\text { Nilai total } \\
\left(\mathbf{x} . \mathbf{f}_{\mathbf{i}}\right)\end{array}$ \\
\hline 40 & 1 & 40 \\
\hline 50 & 3 & 150 \\
\hline 55 & 1 & 55 \\
\hline 60 & 5 & 300 \\
\hline 65 & 4 & 260 \\
\hline 70 & 4 & 280 \\
\hline 75 & 9 & 675 \\
\hline 80 & 6 & 480 \\
\hline 85 & 3 & 255 \\
\hline 90 & 1 & 90 \\
\hline Jumlah & 37 & 2240 \\
\hline
\end{tabular}

Berdasarkan tabel.3. di atas dapat diketahui bahwa nilai tertinggi adalah 90 dan nilai terendah adalah
40. Siswa yang memperoleh nilai 90 sebanyak 1 orang, siswa yang memperoleh nilai 85 sebanyak 3 orang, siswa yang memperoleh nilai 80 sebanyak 6 orang, siswa yang memperoleh nilai 75 sebanyak 9 orang, siswa yang memperoleh nilai 70 sebanyak 4 orang, siswa yang memperoleh nilai 65 sebanyak 4 orang, siswa yang memperoleh nilai 60 sebanyak 5 orang, siswa yang memperoleh nilai 55 sebanyak 1 orang, siswa yang memperoleh nilai 50 sebanyak 3 orang, siswa yang memperoleh nilai 40 sebanyak 1 orang.

Berdasarkan tes hasil belajar siswa di atas, perhitungan nilai yang digunakan adalah bentuk essey tess, (Sudjana, 2014) maka untuk menentukan rata-rata hitung penelitian menggunakan rumus:

$$
\overline{\mathrm{X}}=\frac{\Sigma \mathrm{x}}{\mathrm{N}}=\frac{2 \mathrm{Bss}}{37}=69,86
$$

Berdasarkan data hasil tes awal kelas kontrol, maka data tersebut dapat digunakan untuk menentukan simpangan baku dengan rumus sebagai berikut ini:

$s^{2}=\frac{\left.(\mathrm{N})\left(\mathrm{x}^{2}\right)-\left(\mathrm{C}^{2}\right)^{2}\right)}{\mathrm{N}(\mathrm{N}-1)}=\frac{37(185425)-(2585)^{2}}{37(\mathrm{9} 7-1)}$ $\mathrm{S}^{2}=\frac{17 \mathrm{~s} 500}{1332}=134,009, \mathrm{~S}=11,58$

Uji homogenitas antara kelas eksperimen dan kelas kontrol (Sudjana, 2014). Berdasarkan data nilai tes awal hasil belajar siswa, diketahui nilai rata-rata dan simpangan baku hasil belajar siswa sebagai berikut: 
Kelas eksperimen $\quad: \bar{X}=70$ dan $\mathrm{S}^{2}$ $=12,25$

Kelas kontrol $: \bar{X}=69,86$ dan $\mathrm{S}^{2}=11,58$

Selanjutnya untuk melakukan pengujian homogenitas maka nilai tersebut di atas disubsitusikan pada rumus berikut:

$F=\frac{\text { varian terbesar }}{\text { varians terhecil }}=\frac{12,25}{11,58}=1,058$

Karena $F_{\text {tabel }}$ untuk dk penyebut $\alpha=$ $0,05=(\mathrm{n}-1)(32-1)=31, \mathrm{dk}$ pembilang $=\left(\mathrm{n}_{2}-1\right)(37-1)=36$, berada di antara dk pembilang $=31$ dan 36 , maka $F_{\text {tabel }}=1,8$.

Karena $\mathrm{F}_{\text {hitung }}<\mathrm{F}_{\text {tabel }}$ yaitu $1,058<1,8$ maka dapat disimpulkan bahwa kelas eksperimen dan kelas kontrol keduanya homogen.

\section{Hasil Tes Akhir Kelas Eksperimen}

Melalui pemberian tes akhir kepada kelas eksperimen maka dapat dibuat tabel frekuensi hasil belajar siswa, sebagai berikut:

Tabel. 4. Frekuensi Perolehan Skor Tes Akhir Kelas Eksperimen

\begin{tabular}{ccc}
\hline Nilai $(\mathbf{x})$ & $\begin{array}{c}\text { Frekuensi } \\
\left(\mathbf{f}_{\mathbf{i}}\right)\end{array}$ & $\begin{array}{c}\text { Nilai total } \\
\left(\mathbf{x . \mathbf { f } _ { \mathbf { i } } )}\right.\end{array}$ \\
\hline 60 & 1 & 60 \\
\hline 65 & 3 & 135 \\
\hline 70 & 1 & 140 \\
\hline 75 & 5 & 300 \\
\hline 80 & 4 & 240 \\
\hline 85 & 4 & 425 \\
\hline 90 & 9 & 630 \\
\hline 95 & 6 & 570 \\
\hline 100 & 3 & 200 \\
\hline Jumlah & 32 & 2695 \\
\hline
\end{tabular}

Berdasarkan tabel 4 di atas dapat diketahui bahwa nilai tertinggi adalah 100 dan nilai terendah adalah 60, yaitu siswa yang memperoleh niali 100 sebanyak 2 orang, siswa yang memperoleh niali 95 sebanyak 6 orang, siswa yang memperoleh niali 90 sebanyak 7 orang, siswa yang memperoleh niali 85 sebanyak 5 orang, siswa yang memperoleh niali 80 sebanyak 3 orang, siswa yang memperoleh niali 75 sebanyak 4 orang, siswa yang memperoleh niali 70 sebanyak 2 orang, siswa yang memperoleh niali 65 sebanyak 2 orang, dan siswa yang memperoleh niali 60 sebanyak 1 orang.

Berdasarkan tes hasil belajar siswa di atas, perhitungan nilai yang digunakan adalah bentuk essey tess, maka untuk menentukan rata-rata hitung penelitian menggunakan rumus:

$$
\overline{\mathrm{X}}=\frac{\sum \mathrm{x}}{\mathrm{N}}=\frac{2695}{32}=84,22
$$

Berdasarkan rata-rata hasil belajar siswa pada tes akhir di kelas eksperimen dapat disimpulkan bahwa rata-rata hasil belajar kelas eksperimen termasuk kategori baik (Arikunto, 2006).

Berdasarkan data hasil belajar (tes akhir) kelas eksperimen, maka data tersebut dapat digunakan untuk menentukan simpangan baku dengan rumus sebagai berikut ini:

$$
\begin{aligned}
& S^{2}=\frac{\left.(\mathrm{N})\left(\mathrm{Ex}^{2}\right)-(\mathrm{CX})^{2}\right)}{\mathrm{N}(\mathrm{N}-1)}=\frac{\mathrm{n}(2005 \mathrm{~s})-(20 \% 5)}{32(32-1)} \\
& S^{2}=\frac{118775}{992}=114,69, S=10,71
\end{aligned}
$$




\section{Harefa}

\section{Hasil Belajar Kognitif Siswa Kelas Kontrol}

Melalui pemberian tes akhir kepada kelas kontrol maka dapat dibuat tabel frekuensi hasil belajar siswa, sebagai berikut:

Tabel. 5. Frekuensi Perolehan Skor Tes Akhir Kelas Kontrol

\begin{tabular}{|c|c|c|}
\hline Nilai (x) & $\begin{array}{c}\text { Frekuensi } \\
\left(\mathbf{f}_{\mathbf{i}}\right)\end{array}$ & $\begin{array}{l}\text { Nilai total } \\
\left(\mathbf{x . f _ { i } )}\right.\end{array}$ \\
\hline 45 & 1 & 45 \\
\hline 50 & 1 & 50 \\
\hline 55 & 3 & 165 \\
\hline 60 & 4 & 240 \\
\hline 65 & 3 & 195 \\
\hline 70 & 3 & 210 \\
\hline 75 & 6 & 450 \\
\hline 80 & 7 & 560 \\
\hline 85 & 5 & 425 \\
\hline 90 & 2 & 180 \\
\hline 95 & 1 & 95 \\
\hline 100 & 1 & 100 \\
\hline Jumlah & 37 & 2715 \\
\hline
\end{tabular}

Berdasarkan tabel 5 di atas dapat diketahui bahwa nilai tertinggi adalah 100 dan nilai terendah adalah 45, yaitu siswa yang memperoleh nilai 100 sebanyak 1 orang, siswa yang memperoleh nilai 95 sebanyak 1 orang, siswa yang memperoleh nilai 90 sebanyak 2 orang, siswa yang memperoleh nilai 85 sebanyak 5 orang, siswa yang memperoleh nilai 80 sebanyak 7 orang, siswa yang memperoleh nilai 75 sebanyak 6 orang, siswa yang memperoleh nilai 70 sebanyak 3 orang, siswa yang memperoleh nilai 65 sebanyak 3 orang, siswa yang memperoleh nilai 60 sebanyak 4 orang, siswa yang memperoleh nilai 55 sebanyak 3 orang, siswa yang memperoleh nilai 50 sebanyak 1 orang, dan siswa yang memperoleh nilai 45 sebanyak 1 orang. Berdasarkan tes hasil belajar siswa di atas, perhitungan nilai yang digunakan adalah bentuk tes pilihan ganda, maka untuk menentukan ratarata hitung penelitian menggunakan rumus:

$$
\overline{\mathrm{X}}=\frac{\sum x}{\mathrm{~N}}=\frac{2715}{37}=73,39
$$

Berdasarkan rata-rata hasil belajar siswa pada tes akhir di kelas ekperimen kedua dapat disimpulkan bahwa rata-rata hasil belajar termasuk kategori baik.

Berdasarkan data hasil belajar (tes akhir) kelas eksperimen II, maka data tersebut dapat digunakan untuk menentukan simpangan baku dengan rumus berikut ini:

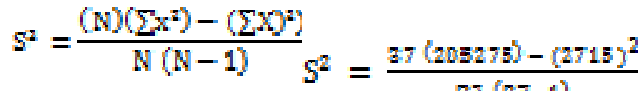

$$
\begin{aligned}
& =\frac{22 m 50}{1322}=168,131, \mathrm{~S}=12,97
\end{aligned}
$$

Berdasarkan perolehan nilai rata-rata hitung dan simpangan baku tes akhir belajar siswa, selanjutnya untuk melakukan pengujian hipotesis, perolehan data dari hasil ulangan harian (tes akhir) hasil penelitian maka diperoleh data:

Kelas eksperimen: $\bar{x}=84.22$ dan $\mathrm{S}^{2}=$ 114,693

Kelas kontrol : $\bar{x}=73,39$ dan $\mathrm{S}^{2}=$ 168,131

Selanjutnya data tersebut di atas disubsitusikan pada rumus uji t, dan sebelumnya terlebih dahulu dihitung nilai $\mathrm{S}$ gabungan, sebagai berikut:

$$
\mathrm{S}^{2}=\frac{\left(m_{1}-1\right) s_{1}^{2}+\left(m_{2}-1\right) \omega_{2}^{2}}{=}=
$$

$\frac{(22-1) \times 114,092+(27-1) \times 180,121}{72+77-2}=\frac{700,172}{67}=$ $143,406, S=11,975$. 
Setelah diperoleh nilai $\mathrm{S}$ gabungan, selanjutnya dilakukan perhitungan nilai t hitung: Pengujian hipotesis yang digunakan adalah uji ttest dengan 2 jumlah sampel $\mathrm{n}_{1}=\mathrm{n}_{2}$ dan varians homogen sebagai berikut:

$$
\begin{aligned}
& \mathrm{t}=\frac{x_{1}-x_{2}}{s \sqrt{\frac{1}{m_{1}}+\frac{1}{m_{2}}}}=\frac{84,22-75,89}{11,975 \times \sqrt{\frac{1}{32}+\frac{1}{37}}}=\frac{10,03}{11,975 \times 0.241} \\
& =\frac{10,83}{2.891}=3,746
\end{aligned}
$$

Berdasarkan perhitungan uji hipotesis diketahui $t_{\text {hitung }}$ sebesar 3,746 kemudian dikonsultasikan pada tabel harga $t$ dengan taraf signifikan 0.05 dimana $t_{\text {tabel }}$ sebesar 1.668 yang berarti $t_{\text {hitung }}=3,746>t_{\text {tabel. }}=1,668$ maka Ha diterima dan Ho ditolak pada taraf signifikan 5\% yang artinya "ada peningkatan prestasi belajar IPA pada model pembelajaran Learning Cycle dengan materi energi dan perubahanya.

\section{Pembahasan}

Pembahasan temuan penelitian ini didasarkan pada tujuan penelitian, kajian pustaka, temuan sebelumnya dan keterbatasan penelitian dengan urutan pembahasan. Untuk lebih jelas dapat diuraikan di bawah ini:

\section{Pelaksanaan Pembelajaran Pada Materi Energi dan Perubahannya dengan Menggunakan Model Pembelajaran Learning Cycle} Sebelum melaksanakan pembelajaran di kelas eksperimen, peneliti melakukan tes awal untuk mengetahui rata-rata hasil belajar siswa sebelum di terapkan model pembelajaran Learning Cycle. Dari hasil analisis data yang dilakukan diperoleh nilai rata-rata siswa sebesar 70, dengan menggunakan model pembelajaran Learning Cycle dilakukan dengan dua kali tatap muka (2 x pertemuan). Setelah melaksanakan pembelajaran dengan menggunakan model pembelajaran Learning Cycle, selanjutnya peneliti melaksanakan tes hasil belajar. Dari hasil analisis data yang dilakukan, diperoleh rata-rata hasil belajar siswa sebesar 84,22 Berdasarkan hasil penelitian menunjukkan bahwa prestasi belajar lebih tinggi dikarenakan penggunaan model pembelajaran Learning Cycle mengarahkan siswa untuk aktif, baik dalam berdiskusi, tanya jawab, mencari jawaban, menjelaskan dan menyimak materi yang dijelaskan oleh teman. Selain itu, model pembelajaran Learning Cycle juga mengarahkan siswa atau anggota untuk bertanggung jawab atas keseluruhan jawaban sebagai tanggung jawab bersama.

2. Pembelajaran Pada Materi Energi dan Perubahannya Menggunakan Model Pembelajaran Konvensional (Metode Ceramah)

Sebelum melaksanakan pembelajaran di kelas kontrol, peneliti melakukan tes awal sebagai pedoman pembentukan kelompok secara heterogen sekaligus untuk mengetahui ratarata hasil belajar siswa sebelum di terapkan model pembelajaran konvensional. Dari hasil analisis data yang dilaukan diperoleh nilai rata-rata siswa sebesar 69,86

Pelaksanaan pembelajaran dengan menggunakan model pembelajaran konvensional dilakukan dengan dua kali tatap muka (2 xpertemuan). Setelah 


\section{Harefa}

melaksanakan pembelajaran dengan menggunakan model pembelajaran konvensional, selanjutnya peneliti melaksanakan tes hasil belajar. Dari hasil analisis data yang dilakukan, diperoleh rata-rata hasil belajar siswa sebesar 73,39. Berdasarkan hasil pengamatan terlihat bahwa siswa kurang aktif, kurang kreatif dan kurang terpacu untuk memahami konsep dari materi yang dipelajari.

3. Implikasi Model Pembelajaran Learning Cycle dan Konvensional Terhadap Peningkatan Prestasi Belajar pada Materi Energi dan Perubahannya.

Model pembelajaran

Learning Cycle dan konvensional telah diterapkan oleh peneliti dalam melaksanakan proses pembelajaran energy dan perubahannya di kelas VI SD Negeri Lagundri. Melihat hasil tes awal dan tes akhir, model pembelajaran Learning Cycle dan konvensional mempunyai implikasi terhadap peningkatan aktivitas dan hasil prestasi belajar siswa serta performansi guru. Kedua model pembelajaran ini terjadi perbedaan pengaruhnya terhadap keaktifan belajar dan hasil belajar siswa.

Prestasi belajar pada penelitian ini dilihat dari prestasi belajar pada aspek kognitif (hasil belajar kognitif). Hasil belajar kognitif adalah kemampuan yang diperoleh siswa pada materi energi dan perubahannya di kelas VI SD Negeri Lagundri.

Berdasarkan hasil penelitian dilihat dari rata-rata prestasi belajar siswa dapat diambil kesimpulan bahwa ada perbedaan hasil belajar siswa melalui model pembelajaran Learning Cycle dengan model pembelajaran konvensional. Pada model pembelajaran Learning Cycle (di kelas eksperimen) ditemukan bahwa rata-rata prestasi belajar siswa pada tes awal adalah 70 sedangkan pada model pembelajaran konvensional (di kelas kontrol) rata-rata hasil belajar siswa pada tes awal adalah 69,86. Berdasarkan hasil tes akhir di kelas eksperimen rata-rata hasil belajar siswa sebesar 84,22, sedangan rata-rata hasil belajar di kelas kontrol sebesar 73,39.

Perbandingan rata-rata hasil belajar pada tes awal dapat di simpulkan bahwa ada perbedaan peningkatan prestasi belajar IPA siswa pada model pembelajaran Learning Cycle (di kelas eksperimen) dan model pembelajaran Konvensional (di kelas kontrol). Rata-rata hasil belajar pada tes awal di kelas eksperimen sebesar 70 sedangkan rata-rata hasil belajar pada tes awal di kelas kontrol sebesar 69,86. Sedangkan perbandingan rata-rata hasil belajar pada tes akhir dengan menggunakan model pembelajaran Learning Cycle dan Konvensional juga dapat disimpulkan bahwa ada perbedaan hasil belajar siswa pada mata pelajaran IPS Terpadu dengan menggunakan model pembelajaran Learning Cycle (di kelas eksperimen) dan model pembelajaran Konvensional (di kelas kontrol). Rata-rata hasil belajar pada tes akhir di kelas eksperimen sebesar 84,22 sedangkan rata-rata hasil belajar pada tes akhir di kelas kontrol sebesar 73,39. 
Berdasarkan rata-rata hasil belajar di atas, dapat disimpulkan bahwa ada peningkatan prestasi belajar IPA siswa pada Model Pembelajaran Learning Cycle Kelas VI SD Negeri Lagundri.

\section{SIMPULAN}

Disimpulkan bahwa dengan diterapkan model pembelajaran Learning Cycle mampu membuat siswa aktif memanfaatkan peluang untuk situasi yang baru karena dengan menggunakan model pembelajaran learning cycle siswa diajak untuk berpartisipasi aktif dalam pembelajaran. Dengan demikian pada pelaksanaan penelitian ini dapat disimpulkan bahwa terjadi peningkatan prestasi belajar IPA siswa pada model pembelajaran learning cicle dengan materi energi dan perubahannya.

\section{DAFTAR RUJUKAN}

Arikunto, S. (2006). Prosedur Penelitian Suatu Pendekatan Praktek. PT Rineka Cipta.

Aunurrahman. (2016). Belajar dan Pembelajaran. Alfabeta.

Benny, P. (2009). Model desain sistem pembelajaran. PT Dian Rakyat.

Hamdani. (2010). Strategi Belajar Mengajar. Pustaka Setia.

Harefa, D. (2017). Pengaruh Presepsi Siswa Mengenai Kompetensi Pedagogik Guru Dan Minatbelajar Siswa Terhadap Prestasi Belajar Ilmu Pengetahuan Alam (Survey pada SMK Swasta di Wilayah Jakarta Utara). Horison Jurnal Ilmu Pendidikan Dan Lingusitik, 7(2),
49-73.

Harefa, D. (2018). Efektifitas Metode Fisika Gasing Terhadap Hasil Belajar Fisika Ditinjau Dari Atensi Siswa (Eksperimen Pada Siswa Kelas Vii Smp Gita Kirtti 2 Jakarta). Faktor Jurnal Ilmiah Kependidikan, 5.

Harefa, D. (2019). Peningkatan Prestasi Rasa Percaya Diri Dan Motivasi Terhadap Kinerja Guru IPA. Media Bina Ilmiah, 13(10), 1773-1786.

https://doi.org/https://doi.org/10. 33758/mbi.v13i10.592

Istarani. (2012). 58 Model Pembelajaran Inovatif Referensi Guru Dalam Menentukan Model Pembelajaran. PT. Media Persada.

Khairani, M. (2013). Psikologi Belajar. Aswaja Pressindo.

Mulyasa. (2006). Menjadi Guru Profesional Menciptakan Pembelajaran Kreatif. Alfabeta.

Rusman. (2012). Seri Manajemen Bermutu Model-Model Pembelajaran Mengembangkan Profesionalisme Guru Edisi Kedua. PT. Raja Grafindo.

Sardiman. (2011). Interaksi dan Motivasi Belajar-Mengajar. Raja Grafindo Persada.

Shoimin, A. (2014). 68 Model Pembelajaran Inovatif dalam Kurikulum 2013. AR-Ruzz Media.

Slameto. (2010). Belajar dan FaktorFaktor Yang Mempengaruhi. 


\section{Harefa}

Rineka Cipta.

Sudjana, N. (2014). Penelitian Hasil Proses Belajar Mengajar. Remaja Rosdakarya.

Syah, M. (2015). Psikologi Pendidikan dengan Pendekatan Baru. Bandung: PT Remaja Rosdakarya.

Trianto. (2014). Model Pembelajaran Terpadu. PT Bumi Aksara. 